\title{
Rivet's mission in colonial Indochina (1931-1932); Or, the failure to create an ethnographic museum
}

Nélia Dias

In January 1932, Paul Rivet, director of the Musée d'Ethnographie du Trocadéro (MET), presided over the First Prehistoric Congress of the Extreme Orient (Hanoi) there he presented a paper entitled, "The Oceanic People" (Rivet 1933). The idea for this First Congress came directly from the Governor-General of Indochina, Pierre Pasquier, with the scientific support of the École Française d'Extrême-Orient (EFEO). ${ }^{1}$ With a medical degree and fieldwork experience in a French geodesic mission in Ecuador (1901-1906), Rivet was not the most qualified French scholar to preside over such an event. His appointment immediately raises questions regarding the Congress's political motivation. Why were Indochinese colonial authorities willing to sponsor this scientific event, and why did they choose Rivet as its president?

It was not the first time that the centralized authority, the Government General of Indochina had sponsored a scientific event. Founded in 1925, the Institut d'Ethnologie de Paris (IEP) was subsidized by the Ministry of the Colonies; and thanks to its Governor-General, Indochina, along with other French colonies, contributed half of the IEP budget in 1926 and in 1927 (Laurière 2008, 348). Rivet was one of the founders of the IEP, along with Lucien Lévy-Bruhl and Marcel Mauss. There were therefore good institutional and political reasons for him to visit French Indochina in the wake of the political events which unfolded there in the early 1930s.

On February 10, 1930, the Vietnamese Nationalist Party organized an insurrection against the French authorities in Yên Bái (Tonkin, in the north of modern Vietnam) which was violently repressed. In the same year, "peasants revolted against the mandarins and the French, forming the Nghê Tinh Soviets, which came to be 
supported by the newly founded Indochinese Communist Party" (Salemink 1991, 260). This rebellion was also repressed. As Pierre Brocheux and Daniel Hémery note "for Vietnam, 1931 and 1932 were the years of the first great mass repression of the twentieth century" attesting to the fragility of French colonial power $(2009,319)$.

On the eve of the opening of the Colonial Exposition in Paris, in April 1931, the French police detained thirty-three Vietnamese, most of whom were students at a meeting where the main speaker was Nguyen Van Tao, a member of the Central Committee of the newly formed Indochinese Communist Party (Lebovics 1992, 98). It was precisely at a moment of political tension and criticism of colonial policies, in both the metropole and in French Indochina, that Rivet was invited to preside over the Congress and to undertake a four-month ethnological research program in French Indochina with the support of the EFEO. The first meeting between Rivet and Pasquier took place during the 1931 Colonial Exposition, when the issue of developing Indochinese ethnography and folklore was debated. Rivet pointed out that some of the IEP's students were specializing in Asian studies, and thus would become the next generation of fieldworkers. ${ }^{2}$

It was in this context of rise of Vietnamese nationalism and political unrest that the French colonial government and army "turned their attention to the strategic Central Highlands, from which most of Indochina could be controlled" (Salemink 1991, 261). This led to a renewed ethnographic focus on the ethnic groups inhabiting this region. It was during this time, too, that new governmental conceptions of the relationships between France and its colonies took shape under the notion of Greater France, which regarded colonies as integrative parts of the French nation that were to be valued for their contribution to the cultural diversity of the colonial power (Levy 1932; Wilder 2005, 29-36). Questions concerning the place of indigenous cultures under colonial rule were thus of paramount concern in this renewed ethnographic attention focused on the Highland populations.

This paper, focused on Rivet's mission, explores, on the one hand, the collecting practices conducted by the EFEO and the relationships between local collectors and the MET. It examines how the relations between the field and the metropolitan centre of calculation (Latour 1987) were organized by pointing out the circulation of 
knowledge, people, and objects from metropolis to colony and vice-versa. On the other hand, the paper examines how ethnographic collecting practices focused on the Moï (savage, a pejorative term used by the French to designate the hill and forestdwelling people of central Vietnam) from 1932 onwards, were related to administrative attempts to control the Highland population. By stressing "the essential cultural unity" of the Montagnards, ethnographic writing "provided the administration both with tools for cultural management and with an appropriate ideological legitimation for their direct-rule policy, aimed at keeping ethnic Vietnamese out" (Salemink 1999, 295). Colonial administration needed to produce discrete ethnic groups as part of the divide and rule policies of the Greater France era and, as Peter Pels and Oscar Salemink have pointed out, "these distinctions were often the source of the ethnographic traditions into which professional ethnographers arrived in the 'field'; in fact, they often made up the definition of the 'field' itself" $(1999,27)$. Ethnographic knowledge associated with fieldwork practices of collecting converged with rational administrative practices for managing colonial populations. The fieldwork phase in anthropology involved a re-articulation of the connections between museums and anthropology "as both come to be implicated in the development of new forms of colonial governmentality" (Bennett 2009, 99). It was as director of a metropolitan museum that Rivet went to Indochina as a site of collection at a time when French colonial authority was contested. While the collections assembled for the MET were to be exhibited for the metropolitan population, those gathered for the colony museums were deemed to serve the administrators in the conduct of colonial populations. Collections mediated the relations between government and populations, thus entailing two distinct forms of governing strategies, which are interpreted in the light of Michel Foucault's (2007, 19-21) notion of the "transactional realities" through which the practices of government come to act on the population, as operating through the mechanisms of "the public" (metropolitan population) and of "the milieu" (colonial population) respectively. However, the failure to create a distinct ethnographic museum in Indochina, in spite of several unrealized projects, ultimately attests to the French failure to manage the Highland population.

\section{Rivet's collecting practices and the EFEO ethnographic inquiry}


From 18 December 1931 to April 1, 1932, Rivet travelled throughout Indochina collecting objects both for the MET and for the forthcoming ethnographic museum in Dalat and established a network of local collectors. His initiatives were complemented by the EFEO ethnographic inquiry and by specific methodological instructions. The circulation of people, information and objects from Indochina to Paris and back again highlight the ways in which the EFEO functioned as a centre of calculation both in the metropole and in the colony.

Rivet's mission to French Indochina under the auspices of the EFEO attests to the theoretical shifts presiding over this institution. Created in 1898 and based first in Saigon and later in Hanoi, the EFEO was the main research centre focused on the archaeology and linguistics of ancient Asian civilizations (Clémentin-Ojha and Manguin 2001; Dartigues 2005; Singaravélou 2009). The EFEO progressively extended its competencies to include ethnology and the study of contemporary ethnic groups by creating in 1937 an Ethnological Service under the direction of Paul Lévy (Clémentin-Ojha and Manguin 2001, 176-178). This was responsible for conducting surveys and for organizing several ethnographic museums and/or ethnographic sections in archaeological museums. The EFEO's new concern in studying contemporary Indochinese "ethnic groups" alongside the study of ancient civilizations is far from accidental. Since the 1880 s and the 1890 's, the French administration had adopted the policy of races (politique des races), a strategy conceived by General Galliéni based on the divide and rule policy. This policy implied the identification and classification of "ethnic groups", therefore making ethnographic knowledge central to colonial governance, as Galliéni acknowledged when he equated the ethnographic mapping of the territory with its pacification (Salemink 2003, 62). The principle that each race should evolve within its own traditions and should therefore be governed differently was promoted by Albert Sarraut, Governor-General of French Indochina from 1917 to 1919, whose book, La mise en valeur des colonies françaises (1923), helped to disseminate the notion of mise en valeur associated with a "program of rational, scientific, and progressive colonial development, in which the state would play a central role" (Conklin 1997, 43).

French-ruled Indochina encompassed a federation of colonies and protectorates in what was then called the Indochinese Union: this included the colony of Cochinchina 
(the southernmost part of modern Vietnam) and the protectorates of Laos, Tonkin (in north Vietnam), Annam (the central region of present-day Vietnam) and Cambodia. Where a regime of direct administration (administration directe) prevailed in the colony ruled by a Governor-General, the French rule in the protectorates was through Résidents at the head of different provinces. These were under the authority of the Résident supérieur who governed through indigenous rulers and mandarins; that is, through preexisting native political structures. This form of government was equated with the policy of association (Betts 1961; Conklin 1997) and in the case of French Indochina, as David Del Testa has pointed out, "association implied that the French, on the one hand, and Cambodians, Laotians, and Vietnamese, on the other, would work together without sacrificing their own cultural identities for mutually beneficial growth", thus allowing "indigenous peoples to preserve 'valid' parts of their local culture and therefore maintain social cohesion and political peace" $(2002,185)$.

The assumption that native social and political structures were adapted to indigenous groups and to the milieus that shaped them was constitutive of the colonial form of government in its relation to indigenous populations. Implementing colonial policies implied acting on those milieus by means of public works, sanitation and education. As Herman Lebovics has pointed out, schools in the colony were urged "to provide more instruction in Vietnamese language and literature, history, and Indochinese and Asian geography" (1992,116). School-texts were intended "to re-orient students back to traditional cultures and societies, which were reconfigured in terms that concurred with the imperative to maintain French hegemony" (Ha 2003, 114).

The emphasis on native language was a way of excluding colonial subjects from French citizenship, since access to the status and rights of citizenship required a command of French language and knowledge of French culture. Moreover, the colony and the protectorates had distinct civic status for their populations; "a subject (as were residents of Cochinchina) could petition for French citizenship ... a protégé (as were residents of Cambodia and Laos) could petition to be naturalized" (Firpo 2007, 217). By focusing on the preservation of "traditional" ways of life, indigenous customs and institutions, the French administration emphasized the role played by indigenous cultural milieus, thus making ethnographical knowledge crucial for governing colonial populations. As Emmanuel Saada (2007) has noted several former governors 
of French Indochina, such as Paul Bert and Jean-Louis de Lanessan, were fervently neo-Lamarckian; the notion of milieu was deployed both to deny French citizenship (where individuals were too embedded in their native cultural milieu) and to award it (where individual were sufficiently assimilated to the French milieu, as in the case of the métis).

From 1900 to 1930, the EFEO created and/or had scientific control over eight museums, mainly archaeological ones, in Hanoi, Saigon, Tourane, Hué, Thanh Hoa, Laos, and Phnom Penh (Clémentin-Ojha and Manguin 2001, 213-222; Singaravélou 2009, 79-80). Far from being a mere random gathering of objects, the EFEO collections were systematically collected according to clearly specified methodological protocols. An ethnographic museum in Indochina under joint directorship of the EFEO and the Governor-General of Indochina had been planned since the 1920s. A museum commission was created by decree in July $1929^{3}$ but it was only in the wake of Rivet's mission to Indochina that these initiatives took concrete shape. In April 30, 1932, Pierre Pasquier signed a decree creating an ethnographic museum in Dalat (100 miles northeast of present day Ho-Chi Minh City), which was to be placed under the authority of the EFEO. This decree coincided with the end of Rivet's mission and his lobbying for the creation of an ethnographic museum. According to the decree, the museum would be devoted to the "study of the material civilization of the diverse ethnic groups inhabiting French Indochina, the civilized people (Annamites, Cambodians and Laotiens) as well as the primitive populations from Haut-Tonkin, Laos and the Annamite chain." ${ }^{4}$ The ethnographic museum was to include a building for displaying collections and a park with replicas of diverse types of habitation in Indochina. Although the decree explicitly stated that the museum would be dedicated to civilized people as well as to "primitive populations", in fact in the eyes of the colonial administration in general, and of the Governor-General in particular, this new institution was mainly charged with the collection of "characteristic objects from indigenous civilizations on the edge of disappearance." 5

The creation of an ethnographic museum in Dalat, a hill-station, was continuously postponed and finally abandoned in 1935 in spite of strong support at the highest levels colonial administrative and scientific circles. Dalat was chosen as it was seen 
by colonial planners as occupying "a strategic point not just in its position vis-à-vis pays like Annam, Cochinchina, or Cambodia, but also with respect to the different ethnies they had classified and categorized" (Jennings 2011, 94). Although a distinct ethnographic museum never came into existence, a Musée de l'Homme was created in Hanoi in 1938 as a part of the Musée Maurice Long, a commercial and industrial museum named after the former Governor-General of Indochina. The creation of this "Musée de l'Homme de Hanoi" was largely due to the efforts of Georges Coèdes, the EFEO's director from 1929 to 1947. On June 11 1938, Coèdes suggested to PierreAndré Pagès, Governor of Cochinchina, that two local ethnographic museums should be created, one in Saigon and the other in Hanoi. ${ }^{6}$ Coèdes's proposal was strategically informed; he took advantage of the Hanoi Fair that was scheduled to open in November 1938 to suggest that a simple ethnographic section should be set up at the Musée Maurice Long. In July 1938, Pagès decreed that half of the space of the Musée Maurice Long should be allocated to the forthcoming ethnographic section, and in November 30, 1938 an anthropological and ethnographic gallery was opened to the public at the same time as the Hanoi Fair and the Congress of Tropical Medicine. Like its metropolitan model, the Musée de l'Homme de Hanoi was supposed to display its objects (mainly musical instruments, weapons, jewelry and cloths) by means of photographs, maps, texts and charts, explaining their use and geographical distribution. $^{7}$

Although the Musée de l'Homme de Hanoi was created under EFEO scientific supervision exercised by Lévy, it was nevertheless a section of the economic museum, the Musée Maurice Long. ${ }^{8}$ But according to Coèdes there was no discontinuity between the two museums; since the Maurice Long museum was devoted to economy and contained local productions, it was already a sort of "ethnological museum", "thus visitors could move naturally from ethnology to economy." This "smooth" shift from ethnology to economy pointed out by Coèdes reflected their close governmental articulation. At a time when the notion of mise en valeur coined by Sarraut was popularized, implying the economic development both of the colony and of its populations, this notion was also used by Rivet and Georges Henri Rivière (the MET assistant director) in order to make France's colonial effort better known. ${ }^{9}$ 
Pasquier's decree creating an ethnographic museum was part of a larger ethnological enterprise including an "ethnographic inquiry", set up in April 1932 and coordinated by Jean-Yves Claeys under the intellectual guidance of Rivet. ${ }^{10}$ Its aim was to assemble Indochinese collections for both the MET and the forthcoming ethnographic museum in Dalat. ${ }^{11}$ Until 1933, the main methodological guide adopted by collectors in Indochina was the Instructions sommaires pour les collecteurs d'objets ethnographiques (1931) conceived by the MET for the Dakar-Djibouti mission (19311933). Several copies of this methodological guide were given by Rivet to local administrators ${ }^{12}$ and the EFEO constantly reminded collectors to ask for these Instructions.

In 1933, the EFEO issued, in collaboration with the IEP, specific methodological instructions, Note pour les collecteurs de l'enquête ethnographique. This Note followed the main principles formulated by the 1931 Instructions- particularly the emphasis on the notion of object as a document itself and on ethnology as "the science that deals with the archives of man". Consequently, ethnography's aim was "to assemble the documents for the study of material civilization", a documentary concern that, as James Clifford has noted, meant that ethnographers were "to amass as complete a corpus as possible: texts, artifacts, maps, photographs, and so forth 'documents' precisely localized and covering a broad range of cultural phenomena" $(1988,65)$. Exhibits reflected this approach in displaying the object along with the documents associated with it.

The EFEO Note contained several additions as well as omissions in comparison with the 1931 Instructions. Three aspects deserve attention. First, the Note focused on the contribution of ethnographic data to archaeological research, a contribution in line with the EFEO's initial mission. Second, the Note emphasized the urgency of assembling, while there was still time, all documents related to Indochina and its ethnic groups, in order to preserve the history and the state of civilization before its transformation as a result of foreign penetration. The focus on the disappearance of cultures and the consequent need to preserve them was undoubtedly part of an "ethnographic salvage" (Gruber 1970) enterprise like others of this period. But the emphasis on "foreign penetration" distinguished the ethnographical inquiries conducted in French Indochina - for the presumed "foreigners" were in fact the ethnic 
Vietnamese (or "Annamites" as the French called them) who were viewed as a threat to the Highland population. As Oscar Salemink has demonstrated, the French administration attempted to pacify the Montagnards ${ }^{13}$ who were considered by the EFEO during the late 1920s and early 1930s as a disappearing "race" (1999, 287); during the same years, an ethnic policy set up by Pasquier aimed to "protect the Montagnards against their more developed and powerful neighbors" $(2003,90)$. This was part of a rhetorical discourse presenting the French as respecting the native's traditions, as evidenced by their willingness to document and preserve them in museum collections, dictionaries and school teaching. Given the strategic importance of the Highlands in terms of controlling Indochina (Salemink 1999, 288), it is not surprising that both Rivet and the EFEO focused their research program on this region.

The third aspect deals with the circulation of information between the metropolitan museum and the colony as a site of collection. Far from being a mere copy of the metropolitan Instructions, the EFEO Note was an adaptation to colonial circumstances of the metropolitan protocols guiding the practices of collecting. Yet, the ways in which the information collected in the field was inscribed in the inventory cards followed the standardized model elaborated by the MET; the EFEO Note explicitly referred to the MET's inventory cards (a Bristol card with a standardized size $13,5 \mathrm{~cm}$ $\mathrm{x} 19,5$ or 5 by 8 inch sheet of paper) as the main tool for describing objects. The inventory card was a tool by which information was selected and knowledge was produced. Each object was given a number; the number inscribed on the object was noted on both the inventory and the inventory card. Far from being a mere textual device, the inventory card was to be complemented with photographs, drawings and films that would help to visualize the ways of using and handling the objects. It was this combination of textual and visual information that conferred on the artifact the status of an ethnographic object worthy of being displayed.

By including certain types of information judged relevant and excluding others, the inventory card was a means of both assembling and standardizing information. As aspect that was implicitly pointed out by Claeys when he suggested to Rivet that, along with the place of origin, province and village, additional information and details about the object's provenance should be included in the inventory cards. For Claeys 
the objects' identification system, which was arranged under general geographical categories, such as Tonkin and Annam, lacked precision because there were at least twenty different ethnic groups in each geographical area. ${ }^{14}$ As an expert in the field, Claeys argued that "from Paris, Indochina looks like a homogeneous whole", while Indochina was, in fact, a carrefour, that is, a cultural crossroad. Claeys's quotation illustrates the two current components, analyzed by Susan Bayly, "of Indochina's cultural 'essences', which prevailed so widely among colonial-era French anthropologists" (2000, 587). The first component stressed the mosaic-like ethnic diversity of Indochina, the second stressed the "dynamic unities of sociality and political order" $(2000,588)$.

Since collectors were supposed to collect two specimens of the same object, there had to be double inventory cards to allow for the circulation of information from the site of collection to the metropolis and vice-versa. In April 1932, Rivet sent Claeys the inventory cards related to the Indochinese objects kept at the MET. In 1933, Claeys sent Rivet several boxes containing objects and complemented them with: (a) a list of the objects; (b) a detailed descriptive list with the object's number and its shelf number in the inventory cards kept at the EFEO. There were, however, two types of circulation: a local circulation (from the field to the local museum or to the EFEO's headquarters) and a global circulation - from Indochina to Paris.

This circulation of information and objects was made possible thanks to a network of collectors set up by Rivet. During his four-month mission, Rivet travelled all over Indochina to collect objects, to establish in each place key informants/collectors who were willing to collaborate with the MET and the EFEO, and to set up an hierarchical team with local informants at the base, coordinated by Claeys and under his own direction. ${ }^{15}$ The organization of ethnological research was thus built on a pyramidal and centralized model, as a form of "rational domination" to use Benoît de l'Estoile's phrase $(2012,101)$.

Rivet could rely on a well-organized team thanks to local informants, who were mostly school-teachers, curators, colonial administrators, and missionaries. For example, Madeleine Colani (with a doctoral degree in science and a regular contributor to the EFEO's Bulletin) had been collecting objects from Laos for the 
MET since October 1931 (that is, before Rivet's mission) in accordance with the 1931 Instructions and using the labels provided by this institution. ${ }^{16}$ Colani's regular exchange with the MET, particularly with Marcelle Bouteiller, and her continuous shipments of objects were at the origin of the exhibit "Jouets Annamites" (Toys from Annam) held at the MET from December 1932 to January 1933 as well as of the opening of an Asian gallery with a huge Indochinese section in January 1934 also at the MET.

Rivet also relied on indigenous collectors, some of whom were trained in Paris. Le Quang-Trong, a Catholic Chinese with a IEP degree, was described as "useful" to the ethnographical inquiry, and was recruited as Claeys' assistant. Nguyen-Van-Huyen (1908-1975) a high school teacher with a Ph.D. from the Sorbonne, was in charge of an ethnographic mission in $1938^{17}$ and became a full time employee at the EFEO a year later.

Rivet hoped that all these local collectors would cooperate with one another ${ }^{18}$, and form what he termed a "small army of auxiliary workers". But like many armies, Rivet's model presupposed a division of labor "between specialists who coordinate and give instructions and volunteers who provide the auxiliary main d'oeuvre for the realization of the work" (L'Estoile 2012, 108). This division of labor entailed a specific conception of how ethnological knowledge was produced: it was through the process of collecting and accumulating data - by means of inventory cards, labels, texts and photos - that further theoretical synthesis could be achieved. In fact, ethnographic inquiry was deemed to be "the first phase" of a larger enterprise aimed to draw "a complete inventory of the social and private life of the diverse ethnic groups inhabiting the Indochinese soil" (Note pour les collecteurs 1933, 484). The distinction between "raw facts" and "synthesis" reflected differences in the roles of local collectors and savants. But it would be misleading to consider local collectors as mere providers of data. If knowledge was accumulated at the MET, each local collector was, as Colani and Clayes' examples demonstrate, indebted to metropolitan knowledge whilst also contributing to it.

Rivet aimed to establish the MET as the coordinating centre of an institutional network of museums operating in different French colonies. The creation of satellite 
museums under the MET's direction was a means of spreading ethnology to the colonies and of standardizing its procedures. The network of research institutes, museums and local learned societies was exhibited through a display of posters at the 1939 World's Fair in New York where the IE and the MH figured as the hub of twenty one "centres d'etudes ethnologiques" (Conklin 2002, 39). If the MET played the role of a coordinating research centre located in the metropolis, the EFEO played a similar role in the colony where it provided methodological expertise, conducted inquiries, and constituted collections that were duplicates of those of the MET. The EFEO thus played the role of a centre of calculation located both in a place of colonial administration and in the metropole. This qualifies Bruno Latour's (1987) distinction between centres of collection and centres of calculation as well as "the implicit centre-periphery logic" underlying it (Introduction).

In a 1939 lecture dedicated to the prehistory and ethnology of Indochina, Paul Lévy emphasized the ways in which Rivet's mission contributed to the duties and interests of colonial administration. Constituting archives of ancient and contemporary Indochinese populations was central both for science and politics; governors need to have a scientific knowledge of the peoples' lives both in the past and in the present in order to guide them in the future (Lévy 1939,49). ${ }^{19}$ The very fact that the sites of collection were at the same time objects of administrative practice, meant that the practices of collecting were connected with practices of colonial governance (Bennett 2009, 104). Rivet's mission took place at a time when French colonial authority was openly contested; by focusing on material culture, he signaled that indigenous populations were a part of Greater France representing a culture that should be cherished both in the colony and in the metropole. This is one of the main differences between what Gary Wilder (2005) calls the "colonial humanism" of the 1930s and earlier forms of colonialism. The concern to establish ethnographic museums in Indochina attests the ways in which expertise on indigenous customs was considered crucial for both metropolitan and colonial authorities. So, why wasn't an ethnographic museum created?

The "small army of auxiliary workers" put in place by Rivet was supposed to map French Indochina's territory and to collect objects representing its ethnic diversity. With a population of 20 million in 1931, collecting had to be selectively focused on 
certain ethnic groups; that the study of the minorities of central Vietnamese highlands was prioritised is no accident. This focus reveals the interconnections between ethnographic practice and colonial governance highlighting what Wilder has designated as "colonial ethnology": "a scientific-administrative complex that included scholars, teachers and administrators, inside and outside the government, in the metropole and overseas, through which practical science and scientific administration constituted one another" $(2003,241)$.

The following section examines why the Montagnards (a term that replaced the pejorative designation Moï) came to be the focus of both administrative and ethnographic concerns. It also points out the failure to create an ethnographic museum in Indochina while archaeological museums were spreading in the 1930s. Local colonial administration had no particular need of an ethnographic museum given the role that ethnography was playing in collecting information about indigenous cultures and milieus that they could use in governmental programs.

\section{The MET and the Montagnards}

Since the French occupation of the Annam in the 1880s, the Moï (Central Highlands population, in present-day Vietnam, consisting of over twenty different languages groups) had played a key role in earlier monographs and ethnographies. ${ }^{20}$ In these works the emphasis was placed on "the codification of the Montagnards customary law for reasons of policing and administration, and the transcription of Montagnard languages for educational policies" (Salemink 1999, 292; 2003, 69-79). In a Circulaire dated July 30, 1923 ( $\mathrm{n}^{\circ} 578$ ) addressed to the residents-chefs of the Annam Province, Pasquier, then Résident Supérieur of Annam, outlined the principles of the racial policy regarding the Moï: "the coutumier (customary laws)" to serve "as the basis for adjudication and administration in the Pays Mö̈”; a coutumier to be "established for every ethnic group" (Salemink 2003, 91-97), primary education to be in "the dominant language of the region" by school teachers belonging "to the same races than their students" (Pasquier 1923 in Variétés 1935, 230); and direct administration. Pasquier acknowledged that laws and customs were not sufficient "to understand and explain the mentality of these people" (1923 in Variétés 1935, 224), and stressed the need to complement knowledge of these with the study of "their 
folklore, their legends, their religious superstitions" considered as an "excellent auxiliary means for grasping and knowing the soul of the men under our administration" (1923 in Variétés 1935, 224-225). The focus on indigenous' culture as a constitutive element of administrative practice was part of the mise en valeur program. Along with the exploitation of the economic resources of the colony, the notion of mise en valeur entailed that colonial populations were considered not as mere workforce but as one of the main richesses of the colony. Sarraut stated it was France's duty to take charge of the Indochinese, conceived as a "retarded brother", to protect him and "le mettre lui aussi en valeur" (Sarraut 1929, XVI). That the issue of developing folklore and ethnography was at the centre of the 1931 meeting between Pasquier and Rivet is far from being accidental at a time when the Montagnards were an object of knowledge for ethnographers and the site of intervention for colonial administration.

As Oscar Salemink has demonstrated, two opposite views on the Moï prevailed throughout the 1920s; one view advocated economic colonization, "a rational exploitation of the land" entailing that the Moï as "savages" would vanish; the second defended a political and strategic colonization implying an ethnic policy $(1991,255)$. In the 1930s, political colonial interests prevailed over economic ones due to the political tensions throughout Indochina leading to a "process of ethnicization of the Montagnards" considered as "a separate ethnic group" (Salemink 1999, 297). Thus, the Montagnards were presented as sharing "an essential cultural unity" regardless of their linguistic differences. In this valorization of Montagnard culture, however, "it was the French who defined what constituted Montagnard culture, which aspects of it were to be preserved, and which aspects were to be changed" (Salemink 1999, 296).

Two publications prepared for the 1931 Colonial Exposition illustrate these two distinct views of the indigenous populations of the Central Highlands. In the Exhibition Guide published by the Government General of Indochina, the Moï were depicted as "real savages" due to the "inexistence of a writing system, reduced agricultural activity, rudimentary social organization and lack of political organization" (Exposition Coloniale 1931, 14). In a volume edited by the EFEO under the direction of the famous Sinologist, Sylvain Lévy, a quite different picture of the Moï emerged. The geographer Charles Robequain, one of the contributors to Lévy's 
volume, asserted that the Highland population was "divided into a great number of tribes which were, upon our arrival, in continuous competition". $(1931,14)$ Although the Moï were less developed than other Indochinese groups, he argued that it would be misleading to consider them as "primitives". ${ }^{21}$ Although the Moï had abandoned their stone instruments, Robequain argued that they possessed technologies, had agricultural practices that distinguished them from primitive nomads as well as distinctive traditions and beliefs (1931, 15). A second contributor, Jean Przyluski, professor of Indochinese history and philology at the Collège de France and former chef de section of indigenous affairs at the Government general of Indochina, interpreted the Moï as sharing an "almost pure Indonesian type", as they were short in height and dolicocephalic (long headed) by contrast with the Vietnamese, who were presumed to be brachycephalic or wide-headed $(1931,49)$. The focus on a physical distinction between the Moï and the ethnic Vietnamese based on anthropometric measurements reflected the administrative imperative of assigning a specific ethnic status to the Moï.

The EFEO volume was also influenced by the Orientalist tradition; for the EFEO's scholars devoted to the archaeology, philology and history of ancient Indochinese civilizations, there was a distinction between these civilizations and the "uncivilized" Montagnards. Although this distinction had its own intellectual and institutional genealogy, reinforced by the epistemological status of "ancient civilizations" within the French academic system (Dartigues 2005), it also echoed the political needs of the administration. Moreover, this distinction helps to explain the failure to create a distinct ethnographic museum in Indochina while archaeological museums were spreading throughout the colony in the 1920s.

Rivet's mission was carried out at the exact time that French policies regarding the Central Highlands were being debated and reformulated. In a speech addressed to the Conseil de Gouvernement in December 1931, Pasquier urged French colonial administrators and civil servants to learn indigenous languages, to establish closer contacts with natives, to multiply their tours and to deliver a primary education by means of school texts in indigenous languages (Pasquier 1931, 9-10). He blamed the growing usage of the telegraph and the automobile for increasing the gap between governors and governed. Pasquier's recommendations need to be placed in a context 
of the growing contestation of French authority in the Highlands with the deaths, in 1931, of one délégué and one engineer (Pasquier 1931, 15; Pagès 1935 in Variétés 1935, 216; Salemink 2003, 106) and the expropriation of Montagnards' lands. Pasquier's attempts to combine "the interests of the colonials with the customs of our protégés" (Pasquier 1923 in Variétés 1935) amounted to limiting the "right of the autochthonous population to the land", allowing European enterprises to establish rubber plantations, thus evicting the Montagnards from their lands and forcing them to work in these plantations (Salemink 1991, 255-259). Along with the renewal of the "pacification campaigns", Pasquier advocated administrative measures based on "the art of knowing and directing the indigenous" $(1931,9)$, in sum an art of governing or a "colonial political rationality" that, according to David Scott, characterizes the "ways in which colonial power is organized as an activity designed to produce effects of rule" (1995,193). "A spirit of benevolence, and a keen desire to be agreeable" should guide the governors in their "art of leading the indigenous" (Pasquier 1931, 10). This form of colonial governmentality operated "to produce not so much extractive-effects on colonial bodies as governing-effects on colonial conduct" (Scott, 1995, 214).

Collecting practices thus formed a part of the "art of knowing and directing" colonial populations in both metropolitan and colonial museums. Rivet collected around 380 objects for the MET, some of which were put on display in 1932 in the exhibit "Exposition de la mission Rivet en Indochine". ${ }^{22}$ Rivet's collection contained around 80 objects from the Moï (Bahnar and Sedang) mainly consisting of weapons (lances and bows) and agricultural tools, particularly machetes. ${ }^{23}$ He noted the differences between the tools for cutting rice used by the Moï from Annam and those used by the Moï from Cambodia; although he didn't provide an explanation for these formal differences, he made drawings of both sort of tools and asked collectors to be attentive to these differences. He also commissioned Paul Gastaldy to create a Moï collection, the contents of which were quite similar to those in Rivet's collection. ${ }^{24}$ Colani's collections were also exhibited at the MET in 1932, later becoming a part of the Asian gallery that opened in 1934.

Barely a month after his return to Europe, Rivet wrote to Pasquier listing his achievements in Indochina and outlining the projects he proposed to carry out in 
France in order to continue with the work of the mission. He praised Pasquier's efforts during the 1930's insurrections, acknowledging that it was "the best attitude to adopt in these troubled times." ${ }^{25}$ Ethnological expertise, by means of collecting objects, establishing museums, and conducting fieldwork inquiries, was thus presented as the "most peaceful" response to indigenous uprisings.

Back in Paris, Rivet dedicated his anthropology course to "our beautiful colony" (Indochina), gave several public lectures on the Moï and a public lecture at the Muséum National d'Histoire Naturelle about the results of his scientific mission; he also planned to give a public lecture at the Guimet Museum based on a "very beautiful Moï movie" made by the Economic Agency of Indochina that he saw in Hanoi. These efforts to promote scientific and popular knowledge about Indochina were in line with the colonial administration's concerns regarding the management of the Moï.

As well as lobbying the Indochinese colonial authorities, Rivet convinced key metropolitan centres to sponsor fieldwork in Indochina. He obtained a Rockefeller grant for his doctoral student, György Dobo, to work on the Moï ${ }^{26}$, a research project conducted under the scientific guidance of the EFEO and of Claeys in particular. Dobo, who adopted the name of Georges Devereux, spent eighteen months among the Sedang (Kontum) and assembled an important collection of objects for the MET; as Devereux acknowledged in a letter to Claeys, it was thanks to the Resident-Supérieur and other colonial administrators who provided "the coolies" that his collection could be shipped to Europe. ${ }^{27}$

Under the direction of Rivet and Rivière, the MET became a centre of teaching and research as well as a centre for public pedagogy that aimed to re-shape popular conceptions of non-Western peoples, in particular those under French authority (Jamin 1989). One of the main discourses disseminated by the MET was that of "all races being equal but different", although Rivet did not question the category of race itself. By collecting objects in Indochina and classifying and displaying them in Paris, the MET aimed to be a valuable resource for knowledge of the colonies. While "pacification campaigns" were conducted in the colony, the MET's exhibits on Indochina were a form of symbolic capture. At the same time, the MET's educational 
and public programs aimed to revise current metropolitan opinions regarding colonial populations as parts of Greater France.

While in the MET the Indochinese collections were displayed for the metropolitan public, in Indochina they were primarily addressed to administrators, tourists and colonial personnel. Ethnographic centers and local museums in the colonies would allow tourists, colonials and civil servants to document in situ the customs of the populations they visited, with whom they worked or who were under their administration (Rivet 1936, 7.08.5).

The creation of an ethnographic museum at Dalat being postponed and a year before the opening of the Musée de l'Homme de Hanoi, Maurice Graffeuil, the Résident supérieur of Annam, proposed to Georges Coèdes (the EFEO director) that an ethnographical collection ${ }^{28}$ related to the "diverse tribes of the Moï regions" should be created and asked the EFEO to provide an ethnographer (this request coincided with the setting up of an Ethnological Service at the EFEO). Rather than relying on the ethnographer's expertise, Graffeuill specified in detail the objects the ethnographer should collect. The Résidents and the heads of the administrative bureau (chefs de postes) were to be the ethnographer's main collaborators in collecting. In less than a week, Coèdes presented a proposal to Pierre Pagès, then Governor-General of Cochinchina, put forward the name of Georgette Naudin (who held a degree in ethnology) and pointed out the budget allocated by Graffeuil for object acquisition. Barely a month later, Pagès received a detailed plan for a local ethnographical museum from J. Ezzaoui, an obscure bureau chief. According to this plan, ethnology was to become, as Ezzaoui put it, "the invisible yet efficient architect of our mission (tâche) in this country". ${ }^{29}$ Graffeuil and Ezzaoui's proposals illustrate the extent to which local colonial administrators and bureau chiefs, familiar with ethnographic knowledge and practices of documentation, could act without ethnographers' expertise. But these examples also highlight the extent to which ethnographic knowledge permeated administrative and political spheres, thus becoming as Ezzaoui put it the "invisible yet efficient architect" of colonial administration.

In the absence of a specific ethnographic collection on the Montagnards, the Musée de l'Homme de Hanoi held an exhibit on the Moï (Kontum) in May 1940 displaying 
objects collected by the résident of Kontum province, Paul Guilleminet. ${ }^{30}$ Along with objects from everyday life and for funeral ceremonies, this exhibit displayed ethnolinguistic maps, photographs and excerpts from the books of Henri Maitre, a famous explorer of the Central Highlands who had played a key role in the penetration of the region and its subsequent pacification (Salemink 2003, 65-67). Although Guilleminet assembled an ethnographic collection, he was much more interested, as later administrateur des services civils of Indochina, in customary laws (1949a). It would, he argued, be misleading to conclude on the grounds of material traits, such as the quasi-absence of cloths, that the Moï were "less developed"; the very fact that they possessed customary laws attested that they were not savages (1949b, 147). In Guilleminet's case, it was ethnography, rather than ethnographic collections per se, that was crucial to colonial governance.

Claeys also left off ethnographic collecting to focus on archaeology in his forthcoming missions. Along with Marcel Ner, Claeys had undertaken an EFEO mission among the Moï in $1937^{31}$ when they photographed houses, funerary statues, tombs, buffalo' sacrifices and ethnic types. ${ }^{32}$ A former civil servant, Ner had been in charge of an EFEO mission to study the Moï of South-Annam and Cambodia since 1936. ${ }^{33}$ Why were collecting and exhibiting ethnographic objects less important in Indochina than in Paris?

While languages and customary law played a crucial role in the process of identification and classification of the Montagnards for administrative purposes (Salemink 1999, 292), material culture did not play a similar role. If, as Rivet had pointed out, formal analogies or differences between objects could help to draw cultural distinctions among the Moï, they were merely one among other elements in the process of classifying and ordering human groups. Moreover, as well as acting on colonized populations through their customs, French colonial practices also focused on the manipulation of milieus. In his 1939 lecture, Claeys thus listed schools, military service, communication roads, and tourism as the "elements of pacification" that would contribute to Moï's submission $(1939,11)$. In this Claeys mapped a field of intervention, which aimed to modify the milieu by affecting the conditions of social life and produce, in Scott's terms, "governing-effects on colonial conduct" (1995, 214). In a context characterized by "the crisis of colonization" as Sarraut stated in 
1931 (as quoted in Brocheux and Hémery 2009, 320) and the rise of Vietnamese nationalism, creating ethnographic museums was not the most pressing priority.

\section{Concluding remarks}

The creation of an ethnographic museum in Indochina was wishful thinking. It was not accidental that the first ethnographic museum was to be located at Dalat, "the France replica" in Jennings terms (2011, 193); as for the Musée de l'Homme de Hanoi, deemed to be a replica of the metropolitan museum, it became a pale image of the Parisian institution.

Collecting practices produced visible results in Paris, with coherent exhibition programs focused on Indochina in general and on the Moï in particular. In contrast, collecting practices in the colony were much less likely to result in exhibitions. The plans for ethnographic museums emanating from the Governor-General and the Résident supérieur mobilized, for a short period, people, material means and institutions, before fading into oblivion. The distinction between "high civilizations" and "savage peoples" helps to explain the contrast between the rise of archaeological museums under EFEO's scientific guidance and the general failure to establish ethnographic museums. In 1923, thanks to Pasquier, the Khai Dinh Museum opened its doors displaying mainly Cham archaeology; from 1924 to 1930 its collections grew from 601 to 4060 objects (Singaravélou 2009, 80). In 1933 a refurbished museum displaying Chinese, Japanese and Vietnamese art and named after the famous orientalist Louis Finot, opened its doors in Hanoi; in the same city, the ethnographic collections were relegated to a section of the economic museum.

Yet for a brief moment, in the early 1930s, the assumption that museums could be involved in the governance of colonial populations pervaded Rivet's undertakings with Pasquier's support. But by replicating the French museological model, as well as its techniques of gathering data, the mentors of these projects underestimated the fundamental differences in the roles that ethnographic museums played for metropolitan populations and for colonials. ${ }^{34}$ 
Notes

1 "Congrès de Préhistoire d'Extrême-Orient", Bulletin de l'École Française d'Extrême-Orient, vol.33, 1933, 493.

${ }^{2}$ Letter from Rivet to Pasquier, 23 March 1931, Archives du Musée de 1'Homme, as quoted in Conklin, 2002,38.

3 "Arrêté créant un musée d'ethnographie en Indochine", Archives EFEO (carton 1010 'Musées - 1901-1954).

4 "Arrêté créant un musée d'ethnographie en Indochine", Archives du Musée de l'Homme, 2 AM 1 D 14 (f).

${ }^{5}$ Lettre 24 September 1932 from Pierre Pasquier aux chefs de l'administration locale et les chefs de service, Archives EFEO, Journal Officiel, October 1,1932.

${ }^{6}$ Letter from G. Coèdes to P. Pagès, 11 June 1938, Archives EFEO (dossier 10-17).

${ }^{7}$ Lettre de G. Coèdes à G. Naudin, 5 July 1938, Archives EFEO (carton 10, dossier 14-17.

8 “Musée de l'Homme, Hanoi", Bulletin de l'École Française d'Extrême-Orient, 1938 : 404.

9 "Nous avons la volonté de faire de notre Musée le grand établissement d'enseignement populaire et de recherche scientifique qu'il doit être, de metre en valeur toutes ses incalculables richesses et de le rendre digne de l'admirable effort colonial de notre pays" in Rivet and Rivière, 1931,10.

10 "Enquête ethnographique", Bulletin de l'École Française d'Extrême-Orient, 1933, vol.33, 414.

${ }^{11}$ Archives EFEO (carton XV - dossier 19 'Enquête ethnographique').

${ }^{12}$ Letter from Rivet to Monsieur le Résident aux administrateurs, May 2, 1932 (Archives du Musée du quai Branly, 2 AM G 2e). Rivet added specific instructions related with the Mongolian spot, 'Instructions sommaires sur la tâche pigmentaire congénitale'.

${ }^{13}$ The term Montagnard referred to the groups inhabiting the mountains and jungles of Annam and those of Laos and of Cambodia, this term replaced the pejorative designation Moï. As Salemink noted the term Montagnard, "seemed less offensive than Moï [...] while sufficiently vague to encompass a wide variety of groups or tribes and being sufficiently French to hint at that 'special relationship"'(1999, 299).

${ }^{14}$ Letter from Claeys to Rivet, July 6, 1932, Archives de l'EFEO (carton XV- 19).

${ }^{15}$ See Rivet's correspondance with Claeys; he sent very regularly long letters, almost reports, about his daily life activities to Claeys and to local administrators, Archives EFEO (carton XV - dossier 19).

${ }^{16}$ Dossier Madeleine Colani, Archives EFEO (carton XV DP P 107).

${ }_{17}$ Cahiers de l'École Française d'Extrême-Orient, nº 15, 1938, 11.

18 "J'aimerais tant voir toutes les personnes de bonne volonté s'entendre et collaborer", Letter from Rivet to Claeys, 20 February 1932, Archives EFEO (carton $\mathrm{XV}$ - dossier 19).

19 “'.... ce qu'a eu de décisif à ce sujet le voyage que fit en 1932 en Indochine M. Le Dr. Paul Rivet, les pouvoirs publics prirent une plus nette conscience de leurs devoirs, et mieux de leurs véritables intérêts. Car s'il est, en effet, important du point de vue scientifique d'avoir sur les populations anciennes et actuelles de l'Indochine les 
archives les plus complètes possibles, il n'en est pas moins essentiel, sans parler du rang que la Science indochinoise est politiquement tenue de garder aussi bien en Extrême-Orient qu'ailleurs, pour les dirigeants de connaître à fond, c'est-à-dire scientifiquement, la vie passée et actuelle des peuples dont le futur leur a été confié", Paul Lévy, 1939, 49.

20 "Ethnographie indochinoise", Bulletin de l'École Française d'Extrême-Orient, 1921, 167-196.

${ }^{21}$ Although in 1913, Marcel Mauss contended that the Moï were not entirely savages but rather "primitive" because they had "institutions and technical productions", therefore in his Manuel d'ethnographie (1947) he considered the Moï of Annam as "archaic and proto-historical" rather than "primitives" like the Australians or the Fuegians.

${ }^{22}$ Letter from Bouteiller to Colani, 18 September 1932, dossier Colani, Archives EFEO (carton XV DP P 107).

${ }^{23}$ Catalogue of the Musée du quai Branly.

${ }^{24}$ Letter from Rivet to Claeys, 29 February 1932, Archives EFEO (carton XV dossier 19). On Gastaldy'collection see Catalogue des objets, Musée du quai Branly.

${ }^{25}$ Lettre from Rivet à Monsieur le Gouverneur Général, 24 May 1932 Archives du Musée du quai Branly, Ms 2/17B.

26 'J'ai obtenu pour l'un de mes meilleures élèves, M. Dobo, une bourse Rockfeller qui lui permettra d'aller passer un an chez les Moï et d'y faire sa thèse", letter from Rivet to Monsieur le Gouverneur Général, 24 May 1932 (Archives du Musée du quai Branly, Ms2 /17B).

${ }^{27}$ For this collection, see the letters exchanged between Devereux and Claeys in August and September 1934, Archives EFEO (carton XV-dossier 17).

${ }^{28}$ Letter from Graffeuil to Coèdes, 19 June 1937, Archives EFEO ( carton 14, dossier 17).

${ }^{29}$ Extrait de la note pour Monsieur le Gouverneur de J. Ezzaoui, 23 July 1937, Archives EFEO (carton 14- dossier 17).

${ }^{30}$ On this exhibit, Archives EFEO (carton 14, dossier 17).

${ }^{31}$ On Claeys and Ner's mission, see Cahiers de l'École Française d'Extrême-Orient, $1937, \mathrm{n}^{\circ} 10,8$.

32760 photographs of the Moï (Bahnar) were taken by Claeys and Ner (Catalogue de l'Iconothèque, Musée du quai Branly).

${ }^{33}$ On Ner's mission, see Cahiers de l'École Française d'Extrême-Orient, 1937, n¹0, 39.

34 The issue of the potential visitors of the ethnographic museums in Indochina is barely mentioned in the official documents.

\section{References}


Bayly, Susan. 2000. "French Anthropology and the Durkheimians in Colonial Indochina". Modern Asian Studies, 34 (3): 581-622.

Bennett, Tony. 2009. "Museum, Field, Colony. Colonial Governmentality and the Circulation of Reference". Journal of Cultural Economy, 2: 99-116.

Betts, Raymond F. 1961. Assimilation and Association in French Colonial Theory, 1890-1914. New York: Columbia University Press.

Brocheux, Pierre and Daniel Hémery. 2009. Indochina. An Ambiguous Colonization, 1858-1954. Berkeley: University of California Press.

Claeys, Jean-Yves. 1939. "A propos des Moï, chasseurs de sang”. Cahiers de l'École Française d'Extrême-Orient,18: 10-18.

Clémentin-Ojha, Catherine and Pierre-Yves Manguin. 2001. Un siècle pour l'Asie. L'École française d'Extrême Orient, 1898-2000. Paris : Les Éditions du Pacifique.

Clifford, James. 1988. The Predicament of Culture. Twentieth-Century Ethnography, Literature, and Art. Cambridge, Ma : Harvard University Press.

Conklin, Alice L. 1997. A Mission to Civilize. The Republican Idea of Empire in France and West Africa, 1895-1930. Stanford : Stanford University Press.

Conklin, Alice L. 2002. "The new 'ethnology' and 'la situation coloniale' in interwar France”. French Politics, Culture \& Society, 20 (2) :29-46.

Dartigues, Laurent. 2005. L'Orientalisme français en pays d'Annam, 1862-1939. Paris : Les Indes Savantes.

Del Testa, David W . 2002. "Workers, Culture, and the Railroads in French Colonial Indochina, 1905-1936". French Colonial History, 2 : 181-198.

Exposition Coloniale de 1931. Section Indochine. 1931. Gouvernement général de l'Indochine, vol.1.

Firpo, Christina E. 2007. "Lost Boys: 'Abandoned'Eurasian Children and the Management of the Racial Topography in Colonial Indochina, 1938-1945". French Colonial History, 8: 203-221.

Foucault, Michel. 2007. Security, Population, Territory: Lectures at the Collège de France, 1978-1979. London: Palgrave Macmillan.

Guilleminet, Paul. 1949a. "La tribu des Bahnars du Kontum". Education,16: 47-63.

Guilleminet, Paul. 1949b. "Coutumes juridiques contemporaines du pays des Bahnars et de leurs voisins". Education, 16: 127-147.

Ha, Marie-Paule. 2003. "From 'Nos Ancêtres les Gaulois' to 'Leur Culture Ancestrale': Symbolic Violence and the Politics of Colonial Schooling in Indochina”. French Colonial History, $3: 101-118$.

Jamin Jean. 1989. "Le Musée d'Ethnographie en 1930: 1'ethnologie comme science et comme politique". In La Muséologie selon Georges Henri Rivière. Paris: Dunod /Bordas: 110-121.

Jennings, Eric T. 2011. Imperial Heights. Dalat and the Making and Undoing of French Indochina. Berkeley: University of California Press.

Latour, Bruno. 1987. Science in Action: How to Follow Scientists and Engineers through Society. Cambridge, Ma: Harvard University Press.

Laurière, Christine. 2008. Paul Rivet, le savant et le politique. Paris : Publications du Muséum National d'Histoire naturelle.

Lebovics, Herman. 1992. True France. The Wars over Cultural Identity 1900-1945. Ithaca and London : Cornell University Press.

L'Estoile, Benoît de. 2000. "Science de l'homme et 'domination rationnelle'. Savoir ethnologique et politique indigène en Afrique coloniale française". Revue de Synthèse, 3-4 : 291-323. 
L'Estoile, Benoit de. 2012. "Internationalization and 'scientific nationalism': the International Institute of African Languages and Cultures between the wars". In Ordering Africa. Anthropology, European Imperialism and the Politics of Knowledge, edited by Helen Tilley and Robert J. Gordon, Manchester: Manchester University Press : 95-116.

Lévy, Paul. 1939. "Préhistoire et Ethnologie en Indochine".Cahiers de l'École Française d'Extrême-Orient, 18: 47-52.

Levy, Roger, 1932. "Indo-China in 1931-1932”. Pacific Affairs, 5(3): 205-217.

- "Note pour les collecteurs de l'enquête ethnographique organisée par l'École Française d'Extrême-Orient en collaboration avec l'Institut d'Ethnologie". Bulletin de l'École Française d'Extrême-Orient, 1933 (33) : 479-485.

Pasquier, Pierre. 1931. Discours prononcé par Monsieur Pierre Pasquier, Gouverneur Général de l'Indochine à l'ouverture de la Session du Conseil de Gouvernement, 8 décembre 1931. Saigon: Imprimerie de la Dépêche.

Pels, Peter and Oscar Salemink. 1994. "Introduction: Five Theses on Ethnography as Colonial Practice". History and Anthropology, 8: 1-34.

Pels, Peter and Oscar Salemink. 1999. "Introduction: locating the colonial subject of anthropology". In Colonial Subjects: Essays on the Practical History of Anthropology edited by Peter Pels and Oscar Salemink, Ann Arbor: The University of Michegan Press: $1-52$.

Przyluski, Jean. 1931. "Les Populations de 1'Indochine française". In Exposition Coloniale Internationale de Paris. Commissariat général. Indochine edited by Sylvain Lévi, Paris: Société d'Éditions Géographiques, Maritimes et Coloniales, 1: 4560.

Rivet, Paul and Georges Henri Rivière. 1931. "La réorganisation du Musée d'Ethnographie du Trocadéro", Bulletin du Musée d'Ethnographie du Trocadéro, 1: 3-11.

Rivet, Paul. 1933. "Les Océaniens”. Bulletin de l'École française d'Extrême-Orient, 33 :492- 496.

Rivet, Paul. 1936. “Ce qu'est l'ethnologie". In L'Encyclopédie française. Volume 7 L'Espèce humaine edited by Lucien Febvre and Anatole de Monzie. Paris : Comité de l'Encyclopédie française, Librairie Larousse: 7.08.1-7.08.16.

Robequain, Charles. 1931. "Le pays et les hommes". In Exposition Coloniale Internationale de Paris. Commissariat général. Indochine edited by Sylvain Lévi, Paris: Société d'Éditions Géographiques, Maritimes et Coloniales,1: 7-43.

Saada, Emmanuelle. 2007. Les Enfants de la colonie. Les métis de l'empire français entre sujétion et citoyenneté. Paris: La Découverte.

Salemink, Oscar. 1991. "Mois and Maquis. The Invention and Appropriation of Vietnam's Montagnards from Sabatier to the CIA". In Colonial Situations. Essays on the Contextualization of Ethnographic Knowledge, edited by George W. Stocking jr., Madison : University of Wisconsin Press :243-284.

Salemink, Oscar. 1999. "Ethnography as Martial Art. Ethnicizing Vietnam's Montagnards, 1930-1954”. In Colonial Subjects: Essays on the Practical History of Anthropology, edited by Peter Pels and Oscar Salemink, Ann Arbor : University of Michegan Press : 282-325.

Salemink, Oscar. 2003. The Ethnography of Vietnam's Central Highlanders: A Historical Contextualization 1850-1990. Honolulu : University of Hawai'i Press.

Scott, David. 1995. “Colonial Governmentality”. Social Text, 43: 191-220. 
Singaravélou, Pierre. 2009. L'École française d'Extrême-Orient ou l'institution des marges (1898-1956). Paris : L'Harmattan.

Sarraut, Albert. 1929. "Préface". In Un Empire colonial français. Indochine, edited by Georges Maspéro, Paris and Bruxelles: Les Éditions G. Van Oest : XI- XXII.

Variétés sur les pays moïs. 1935. Saigon: Gouvernement de la Cochinchine.

Wilder, Gary. 2003. "Colonial Ethnology and Political Rationality in French West Africa". History and Anthropology, 14 (3) : 219-252.

Wilder, Gary. 2005. The French Imperial Nation-State: Negritude and Colonial Humanism between the Two World Wars. Chicago and London: University of Chicago Press. 